\title{
CFD researched on rice husk gasification in a pilot fixed bed up-draft system
}

- Le Thi Kim Phung ${ }^{1}$

- Tran Tan Viet ${ }^{1}$

- Nguyen Luu Minh Thien ${ }^{1}$

- Pham Vuong Viet ${ }^{1}$

- Nguyen Thanh Truc ${ }^{1}$

- Le Anh Kien ${ }^{2}$

- Nghiep Quoc Pham ${ }^{2}$

- Duyen Khac Le ${ }^{2}$

${ }^{1}$ Ho Chi Minh city University of Technology,VNU-HCM

${ }^{2}$ Institute for Tropicalisation and Environment

(Manuscript Received on July, 2016, Manuscript Revised on September, 2016)

\section{ABSTRACT}

Finding alternative energy sources for fossil fuels was a global matter of concern, especially in developing countries. Rice husk, an abundant biomass in Viet Nam, was used to partially replace fossil fuels by gasification process. The study was conducted on the pilot plant fixed bed up-draft gasifier with two kind of gasification agents, pure air and air-steam mixture. Mathematical modeling and computer simulations were also used to describe and optimize the gasification processes. Mathematical modeling was based on
Computational Fluid Dynamics method and simulation was carried by using Ansys Fluent software. Changes in outlet composition of syngas components ( $\mathrm{CO}, \mathrm{CO}_{2}, \mathrm{CH}_{4}, \mathrm{H}_{2} \mathrm{O}, \mathrm{H}_{2}$ ) and temperature of process, in relation with ratio of steam in gasification agents, were presented. Obtained results indicated concentration of $\mathrm{CH}_{4}, \mathrm{H}_{2}$ in outlet was increased significantly when using air-steam gasification agents than pure air. The discrepancies among the gasification agents were determined to improve the actual process.

Keywords: CFD; gasification; rice husk; Ansys Fluent; UDFs.

\section{INTRODUCTION}

With the continuous development of economy and technology, people's living standards were constantly being enhanced and thereby energy demand surged in Vietnam. The primary energy demand was estimated to 
escalate annually at $3.9 \%$, from 38 million tons of oil equivalent (MToe) in 2008 to 109 MToe by 2030 . Vietnam was expected to become a country subjected to significant dependence on energy and an economy importing energy after 2020 [1]. Besides, Vietnam was located in the tropical monsoon area so the plants grow faster. As an agricultural country with a high proportion of the economy, Vietnam has huge biomass energy sources, specially rice husk, the by-products of rice production. So if it takes advantage of the energy from the abundant byproducts of rice, it can meet $27 \%$ of demand for primary energy consumption [2]. Gasification was a potential technology can replace fossil energy sources. Therefore, the study of gasification, sophisticated technology, was one of the urgent issues. Modeling methods, was carried out in recent years, can be divided into 4 groups: thermodynamic equilibrium, kinetic, Computational fluid dynamics (CFD), Artificial neural network [3]. Computational Fluid Dynamics (CFD) can be employed to investigate this process in detail by linking experimental data and numerical simulation and helping to reduce the complexity of experimental work. Gasification was a multiphase model that was mixed with chemical reactions. To solve this model, there were two approaches: the discrete element method (DEM) and Eulerian approaches. For DEM-based simulation, the framework for the application of the natural and physical models was provided. But it was computationally expensive, especially when the chemical reactions were supplemented [4].

In this research, the model was simulated on Ansys Fluent combined UDFs (User Defined Functions) and $\mathrm{C}$ code with Eulerian approaches to model the gasification process. Geometry dimensions, temperature of combustion zones, height of combustion zone in the model were obtained from the pilot updraft gasification system of rice husk. The purpose of this study was to improve the gasification of rice husk and towards optimizing the operational processes.

\section{MODEL DESCRIPTION}

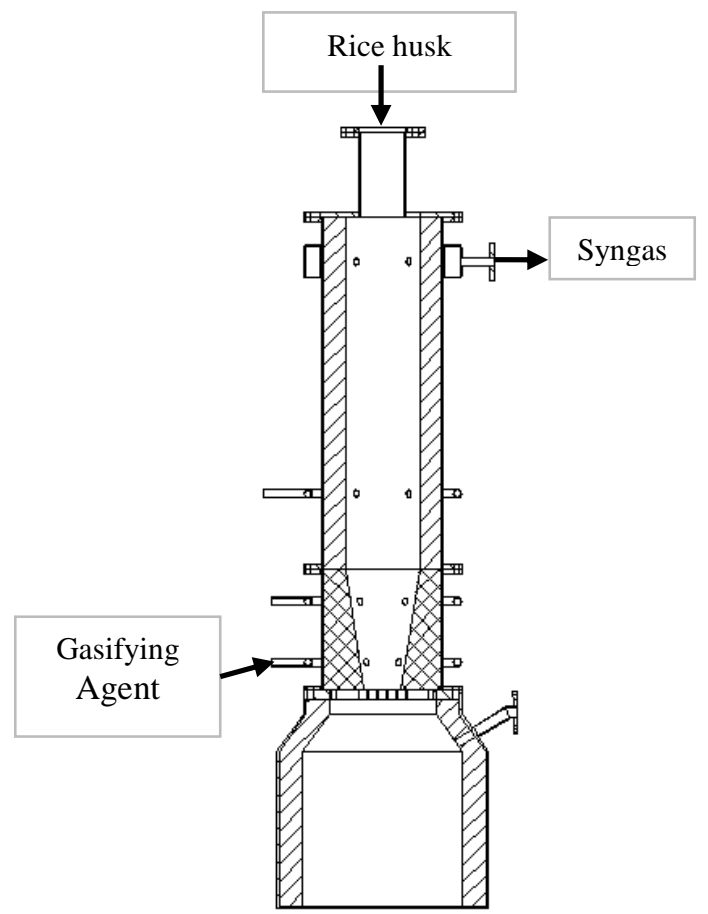

Figure 1. The pilot updraft gasification system.

The pilot updraft gasification system was showed in Figure 1, the gas obtained on the top of gasifier. AutoCAD software was used to create geometry for this system, ICEM CFD was used for the meshing process. Pilot equipment whose height was $740 \mathrm{~mm}$ in cylindrical section, $260 \mathrm{~mm}$ in cone section.

\section{RICEHUSK CHEMICAL FORMULA}


Rice husk was a complex mixture of organic substances consisting mainly of components: Carbon, Hydrogen and Oxygen. Proximate and ultimate analyzes of rice husk were given in Table I and Table II [14].

Table 1. Proximate analysis of rice husk

\begin{tabular}{|l|c|}
\hline Characteristics & \% by weight \\
\hline Moisture & 6.47 \\
\hline Combustible Matter & 81.83 \\
\hline Ash & 11.7 \\
\hline
\end{tabular}

Table 2. Ultimate analysis of rice husk

\begin{tabular}{|l|c|}
\hline Component & $\begin{array}{c}\text { \% by weight dry ash free } \\
\text { basis }\end{array}$ \\
\hline C & 48.69 \\
\hline $\mathrm{H}$ & 6.97 \\
\hline $\mathrm{N}$ & 0.37 \\
\hline $\mathrm{O}$ & 43.97 \\
\hline
\end{tabular}

The identification of the chemical formula of biomass was quite complicated, some approximation method was employed to determine relatively its chemical formula. One approach was based on utilization of elemental composition from ultimate analysis of dry biomass and could be displayed as in Eq (1-3) which was based on a single atom of carbon [5]

Typical chemical formula of biomass was $\mathrm{C}_{\mathrm{c}} \mathrm{H}_{\mathrm{h}} \mathrm{O}_{\mathrm{o}}$.

$$
\begin{gathered}
c=1 \\
h=\frac{H_{\%} \times M_{C}}{C_{\%} \times M_{H}}=1,72 \\
o=\frac{O_{\%} \times M_{C}}{C_{\%} \times M_{O}}=0,68
\end{gathered}
$$

Based on data from Table II, the amount of oxygen was calculated by subtracting the amount of carbon and hydrogen, the formula of the husks was obtained. The molecular mass of biomass was estimated as:

$M_{\text {biomass }}=M_{C} \times c+\frac{M_{H_{2}}}{2} \times h+\frac{M_{O_{2}}}{2} \times O$

\section{MATHEMATICAL MODEL}

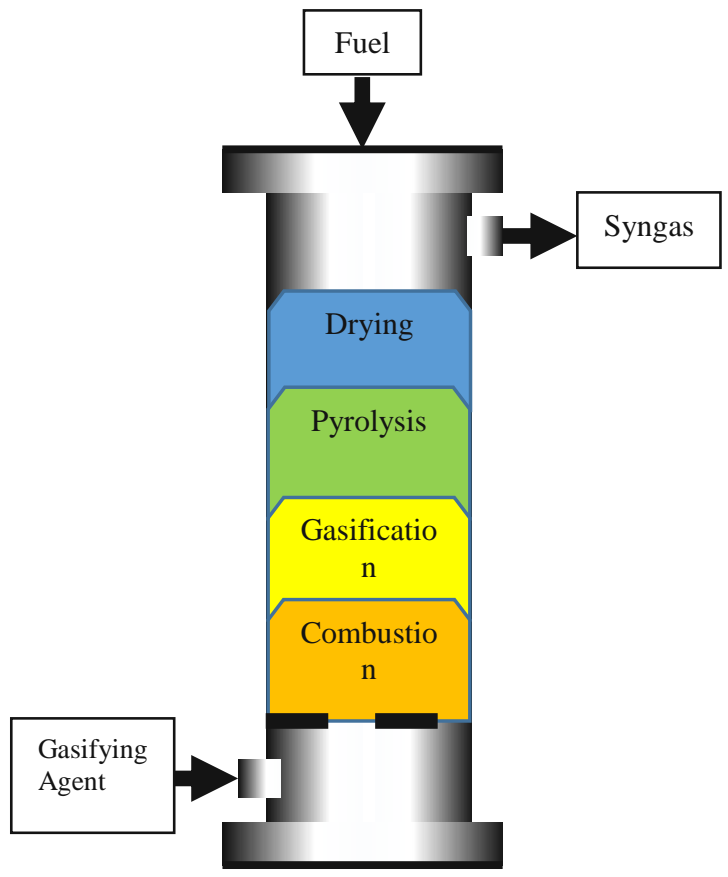

Figure 2. Fied-bed updraft gasifier

Gasification model was divided into 4 zones: drying, pyrolysis, gasification and combustion. Figure 2 showed various zone from updraft gasifier system.

Rice husk was entered in accordance with the composition of the proximate analysis: Combustibles matter, Moisture and Ash. Gasification Scheme was showed in Figure 3. 


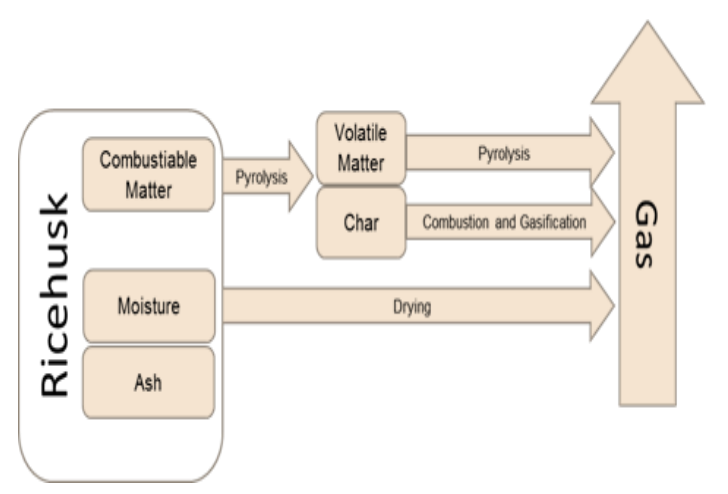

Figure 3. Schematic of the ricehusk gasification

\subsection{Governing Equations}

The mass, energy and species equations of the gas phase and solid phase were described as follow:

1) Mass conservation

Gas Phase

$$
\frac{\partial\left(\varepsilon_{g} \rho_{g}\right)}{\partial t}+\nabla \cdot\left(\varepsilon_{g} \rho_{g} v_{g}\right)=0
$$

Solid Phase

$$
\frac{\partial\left(\varepsilon_{s} \rho_{s}\right)}{\partial t}+\nabla \cdot\left(\varepsilon_{s} \rho_{s} v_{s}\right)=0
$$

2) Energy Equation

Gas Phase

$$
\begin{aligned}
& \frac{\partial\left((1-\phi) \rho_{s} c_{p s} T_{s}\right)}{\partial t}+\nabla\left(\phi \rho_{g} u_{g} c_{p g} T_{g}\right)= \\
& \nabla\left(\lambda_{g} \nabla T_{g}\right)+A_{s} h_{s}^{\prime}\left(T_{g}-T_{s}\right)+S_{T_{g}}
\end{aligned}
$$

Solid Phase

$$
\begin{aligned}
& \frac{\partial\left((1-\phi) \rho_{s} c_{p s} T_{s}\right)}{\partial t}+\nabla\left((1-\phi) \rho_{s} u_{s} c_{p s} T_{s}\right)= \\
& \nabla\left(k_{e f f} . \nabla T_{s}\right)+\left(\nabla q_{r}\right)-A_{s} h_{s}^{\prime}\left(T_{g}-T_{s}\right)+S_{T_{s}}
\end{aligned}
$$

3) Species Equation
Gas Phase

$\frac{\partial\left(\phi \rho_{g} Y_{i g}\right)}{\partial t}+\nabla\left(\phi \rho_{g} u_{g} Y_{i g}\right)=$

$\nabla\left(D_{i g} \nabla\left(\phi \rho_{g} Y_{i g}\right)\right)+S_{Y_{g}}$

Solid Phase

$$
\frac{\partial\left((1-\phi) \rho_{s} Y_{i s}\right)}{\partial t}+\nabla\left((1-\phi) \rho_{s} u_{s} Y_{i s}\right)=S_{Y_{s}}
$$

4) Momentum conservation

Gas Phase

$$
\begin{aligned}
& \frac{\partial\left(\varepsilon_{g} \rho_{g} v_{g}\right)}{\partial t}+\nabla\left(\varepsilon_{g} \rho_{g} v_{g} v_{g}\right)= \\
& -\varepsilon_{g} \nabla p+\nabla \bar{\tau}_{g}+\varepsilon_{g} \rho_{g} g+K_{g s}\left(u_{g}-u_{s}\right)
\end{aligned}
$$

Solid Phase

$$
\begin{aligned}
& \frac{\partial\left(\varepsilon_{s} \rho_{s} v_{s}\right)}{\partial t}+\nabla\left(\varepsilon_{s} \rho_{s} v_{g} v_{s}\right)= \\
& -\varepsilon_{s} \nabla p_{s}+\nabla \bar{\tau}_{s}+\varepsilon_{s} \rho_{s} g+K_{g s}\left(u_{g}-u_{s}\right)
\end{aligned}
$$

\section{5) Porous media}

Porous Media Model was used for describe flow through packed beds. Porous media were modeled by the addition of a momentum source term to the standard fluid flow equations. The source term was composed of two parts: a viscous loss term and an inertial loss term [6].

$$
S_{i}=-\left(\sum_{j=1}^{3} D_{i j} \mu v_{j}+\sum_{j=1}^{3} C_{i j} \frac{1}{2} \rho|v| v_{j}\right)
$$

The permeability and inertial loss coefficient in each component direction could be identified as: 


$$
\begin{gathered}
\alpha=\frac{D_{p}^{2}}{150} \frac{\varepsilon^{3}}{(1-\varepsilon)^{2}} \\
C_{2}=\frac{3.5}{D_{p}} \frac{(1-\varepsilon)}{\varepsilon^{3}}
\end{gathered}
$$

\subsection{Chemical Kinetics Model}

1) Drying

The moisture in the biomass was evaporated as the high-temperature:

$$
\mathrm{H}_{2} \mathrm{O}(\mathrm{l}) \stackrel{r_{d}}{\longrightarrow} \mathrm{H}_{2} \mathrm{O}(\mathrm{g})
$$

Evaporation-Condensation Model in ANSYS Fluent was applied in drying process. The evaporation-condensation model was a mechanistic model with a physical basis. It was available with the mixture and Eulerian multiphase models. Based on the following temperature regimes, the mass transfer can be described as follows: [11]

If $\mathrm{T}>\mathrm{T}$ sat

$$
n_{e \rightarrow v}=\operatorname{coeff} * \alpha_{l} \rho_{l} \frac{\left(T-T_{s a t}\right)}{T_{\text {sat }}}
$$

\section{If $\mathrm{T}<\mathrm{Tsat}$}

$$
\operatorname{mos}_{e \rightarrow v}=\operatorname{coeff} * \alpha_{v} \rho_{v} \frac{\left(T-T_{\text {sat }}\right)}{T_{\text {sat }}}
$$

\section{2) Pyrolysis}

The pyrolysis reaction was expressed as:

$$
\begin{aligned}
& \mathrm{CH}_{h} \mathrm{O}_{o} \rightarrow n_{p, C} \mathrm{C}+n_{p, \mathrm{CO}_{2}} \mathrm{CO}_{2}+n_{p, C O} \mathrm{CO}+ \\
& n_{p, \mathrm{CH}_{4}} \mathrm{CH}_{4}+n_{p, \mathrm{H}_{2}} \mathrm{H}_{2} \\
& +n_{p, \mathrm{C}_{2} \mathrm{H}_{2}} \mathrm{C}_{2} \mathrm{H}_{2}+n_{p, \mathrm{H}_{2} \mathrm{O}} \mathrm{H}_{2} \mathrm{O}
\end{aligned}
$$

Pyrolysis reaction was based on practical assumptions that have been supported by the experimental results of biomass pyrolysis. Several hypotheses for present pyrolysis zone model have been employed which was based on the fact that the connection between $\mathrm{H}$ and $\mathrm{O}$ was far higher than that of $\mathrm{C}$ and $\mathrm{O}[5]$.

$80 \%$ of fuel oxygen $(\mathrm{O})$ was connected with fuel hydrogen $(\mathrm{H})$ in the form of $\mathrm{H}_{2} \mathrm{O}$.

$20 \%$ of fuel oxygen (O) was connected with fuel carbon $(\mathrm{C})$ and releases as $\mathrm{CO}$ and $\mathrm{CO}_{2}$.

The molar ratio of $\mathrm{CO}$ and $\mathrm{CO}_{2}$ was inversely proportional with their molecular mass.

$$
\frac{n_{\mathrm{CO}}}{n_{\mathrm{CO}_{2}}}=\frac{44}{28}
$$

$50 \%$ of available hydrogen in fuel releases as $\mathrm{H}_{2}$ on decomposition.

Remaining $50 \%$ of available hydrogen in fuel was released in the form of $\mathrm{CH}_{4}$ and $\mathrm{C}_{2} \mathrm{H}_{2}$.

Molar ratio of $\mathrm{CH}_{4}$ and $\mathrm{C}_{2} \mathrm{H}_{2}$ was inversely proportional with their molecular mass.

Based on the results we obtained stoichiometric of pyrolysis equation of rice husk was: 
Table 3. Stoichiometry of pyrolysis reaction

\begin{tabular}{|c|c|c|c|c|}
\hline & $\mathrm{C}$ & $\mathrm{CO}_{2}$ & $\mathrm{CO}$ & $\mathrm{CH}_{4}$ \\
\hline $\mathrm{n}_{\mathrm{p}}$ & 0.767 & 0.038 & 0.06 & 0.06 \\
\hline & $\mathrm{H}_{2}$ & $\mathrm{C}_{2} \mathrm{H}_{2}$ & $\mathrm{H}_{2} \mathrm{O}$ & \\
\hline $\mathrm{n}_{\mathrm{p}}$ & 0.158 & 0.037 & 0.544 & \\
\hline
\end{tabular}

The reaction rate of pyrolysis was expressed by the one-step reaction model. [7]

$$
\begin{aligned}
& r_{p}=\rho_{\text {ricehusk }} \times A_{p} \times e^{\left(\frac{E_{p}}{R \times T_{\text {solid }}}\right)} \\
& A_{p}=10^{4.03} 1 / \mathrm{s} \mathrm{E}_{p}=8.79 \times 10^{7} \mathrm{~J} / \mathrm{kmol}
\end{aligned}
$$

\subsection{Char Consumtion}

1) Char Gasification

The reactions occurred in the gasification zone include the gasification reactions of char and water, carbon dioxide and hydrogen.

$$
\begin{aligned}
& \mathrm{C}(\mathrm{s})+\mathrm{H}_{2} \mathrm{O} \rightarrow \mathrm{CO}+\mathrm{H}_{2} \\
& \mathrm{C}(\mathrm{s})+\mathrm{CO}_{2} \rightarrow 2 \mathrm{CO} \\
& C(s)+2 \mathrm{H}_{2} \rightarrow \mathrm{CH}_{4}
\end{aligned}
$$

The reaction rate of char gasification reaction depended on several effects like mass transfer in the gas phase, diffusion, chemical reaction and the particle surface. The overall reaction rate was introduced. [7]

$$
r_{g, i}=\frac{X_{i}}{\frac{1}{k_{g}}+\frac{1}{r_{\text {chem }, g, i}}} * A_{P}
$$

with $\mathrm{i}=\mathrm{H}_{2} \mathrm{O}, \mathrm{CO}_{2}, \mathrm{H}_{2}$

$$
\begin{gathered}
r_{\text {chem }, g, i}=A_{i} * \exp \left(-\frac{E_{i}}{R * T_{\text {solid }}}\right) \\
K_{g}=\frac{2.06 * V_{\text {gas }}}{\varepsilon} * \operatorname{Re}^{-0.575 * \operatorname{Pr}^{-\frac{2}{3}}}
\end{gathered}
$$

Kinetic constants for the gasification reactions were listed in Table 4.

2) Char Combustion

In Combustion Zone, rice husk char oxidized with the supplied air

$$
C+\left(\frac{1-\alpha}{2}\right) O_{2} \rightarrow \alpha C O+(1-\alpha) \mathrm{CO}_{2}
$$

Similarly, to the gasification reactions an overall reaction was introduced [7]

$$
\begin{gathered}
r_{c}=\frac{1}{\left(2 * k_{o x}\right)}+\frac{\mathrm{PO}_{2}}{\left(\frac{M_{\text {gas }}}{M_{\text {solid }}} * r_{\text {chem }, c l}\right)} * A_{P} \\
r_{\text {chem }, c 1}=A_{c 1} * \exp \left(-\frac{E_{c 1}}{R * T_{\text {solid }}}\right)
\end{gathered}
$$

$k_{O X}=\frac{1.57 * v_{\text {gas }} * \rho_{\text {gas }} * S c^{-\frac{2}{3}} * \operatorname{Re}^{-0.41} *(1-\varepsilon)^{0.2}}{M_{\text {gas }} * p}$

The proportion of $\mathrm{CO}$ and $\mathrm{CO}_{2}$ formation was inversely proportional to the exothermicity of their reactions. [5] 


$$
\frac{n_{C O}}{n_{\mathrm{CO}_{2}}}=\frac{\alpha}{1-\alpha}=3.5606
$$

Kinetic constants for the combustion reactions were also listed in Table 3 .

Table 4. Kinetic data of char consumption reaction [8-10]

\begin{tabular}{|l|l|l|l|l|}
\hline Reaction & $\mathrm{A}$ & Unit & $\mathrm{E}$ & Unit \\
\hline $\mathrm{r}_{\mathrm{c}}$ & 4750 & $\mathrm{kgm}^{2} \mathrm{~s} 1$ & $2 \times 10^{8}$ & $\mathrm{~J} / \mathrm{kmol}$ \\
\hline $\mathrm{rg}, \mathrm{H}_{2} \mathrm{O}$ & 107 & $\mathrm{~ms}^{-1} \mathrm{~K}^{-1}$ & $1.256 \times 10^{8}$ & $\mathrm{~J} / \mathrm{kmol}$ \\
\hline $\mathrm{rg}, \mathrm{CO}_{2}$ & 107 & $\mathrm{~ms}^{-1} \mathrm{~K}^{-1}$ & $1.256 \times 10^{8}$ & $\mathrm{~J} / \mathrm{kmol}$ \\
\hline $\mathrm{rg}, \mathrm{H}_{2}$ & 104 & $\mathrm{~ms}^{-1} \mathrm{~K}^{-1}$ & $1.256 \times 108$ & $\mathrm{~J} / \mathrm{kmol}$ \\
\hline
\end{tabular}

\subsection{Homogeneous reactions}

Homogeneous reactions in the gas phase included water - gas shift reaction and combustion reactions between $\mathrm{CO}_{2}, \mathrm{H}_{2}, \mathrm{CH}_{4}$, $\mathrm{C}_{2} \mathrm{H}_{2}$. The kinetic data of combustion reaction obtained from ANSYS FLUENT DATABASE. Table 4 showed kinetic data of gas phase reactions
Table 5. Kinetic data of gas-phase reaction [12-13].

\begin{tabular}{|l|c|c|}
\hline Reaction & $\begin{array}{c}\mathrm{A} \\
\mathrm{kmolm}^{3} \mathrm{~s}^{-1}\end{array}$ & $\begin{array}{c}\mathrm{E} \\
\mathrm{J} \mathrm{kmol}^{-1}\end{array}$ \\
\hline $\mathrm{CO}+\mathrm{H}_{2} \mathrm{O} \leftrightarrow \mathrm{CO}_{2}+\mathrm{H}_{2}$ & 1389 & $1.256 \times 10^{7}$ \\
\hline $\mathrm{CO}+\frac{1}{2} \mathrm{O}_{2} \rightarrow \mathrm{CO}_{2}$ & $1.7 \times 10^{8}$ & $2.239 \times 10^{12}$ \\
\hline $\mathrm{H}_{2}+\frac{1}{2} \mathrm{O}_{2} \rightarrow \mathrm{H}_{2} \mathrm{O}$ & $3.1 \times 10^{7}$ & $9.87 \times 10^{8}$ \\
\hline $\mathrm{CH}_{4}+2 \mathrm{O}_{2} \rightarrow \mathrm{CO}_{2}+$ & $2.027 \times 10^{8}$ & $2.119 \times 10^{11}$ \\
\hline $\mathrm{C}_{2} \mathrm{H}_{2}+2,5 \mathrm{O}_{2} \rightarrow$ & $1.25 \times 10^{8}$ & $3.655 \times 10^{10}$ \\
$2 \mathrm{CO}_{2}+\mathrm{H}_{2} \mathrm{O}$ & & \\
\hline
\end{tabular}

\section{SIMULATION WITH ANSYS FLUENT} CFD

Simulations were conducted on ANSYS FLUENT 14.5 software, the Solver Type was pressure-based, velocity formulation was absolute and type of time was transient. Initial column of rice husk in the model was $450 \mathrm{~mm}$ in length. The amount of gasifying agents was on the speed level of $0.1 \mathrm{~m} / \mathrm{s}$. Steam agent was saturated steam at a temperature of 1 atm: $373 \mathrm{~K}$.

Table 6. Operation conditions for running simulation

\begin{tabular}{|l|l|l|l|l|l|}
\hline \multirow{2}{*}{ Case } & Temp & $\begin{array}{l}\text { Steam/air } \\
\text { Ratio }\end{array}$ & Mole Fraction $\mathrm{O}_{2}$ & Mole Fraction $\mathrm{N}_{2}$ & $\begin{array}{c}\text { Mole Fraction } \\
\mathrm{H}_{2} \mathrm{O}\end{array}$ \\
\cline { 2 - 6 } & $\mathrm{K}$ & $\mathrm{vol} / \mathrm{vol}$ & $\mathrm{mol} / \mathrm{mol}$ & $\mathrm{mol} / \mathrm{mol}$ & $\mathrm{mol} / \mathrm{mol}$ \\
\hline 1 & 300 & 0 & 0.21 & 0.79 & 0 \\
\hline 2 & 314.6 & 0.2 & 0.168 & 0.632 & 0.2 \\
\hline 3 & 329.2 & 0.4 & 0.126 & 0.474 & 0.4 \\
\hline 4 & 343.8 & 0.6 & 0.084 & 0.316 & 0.6 \\
\hline 5 & 358.4 & 0.8 & 0.042 & 0.158 & 0.8 \\
\hline
\end{tabular}




\section{RESULTS AND DISCUSSION}

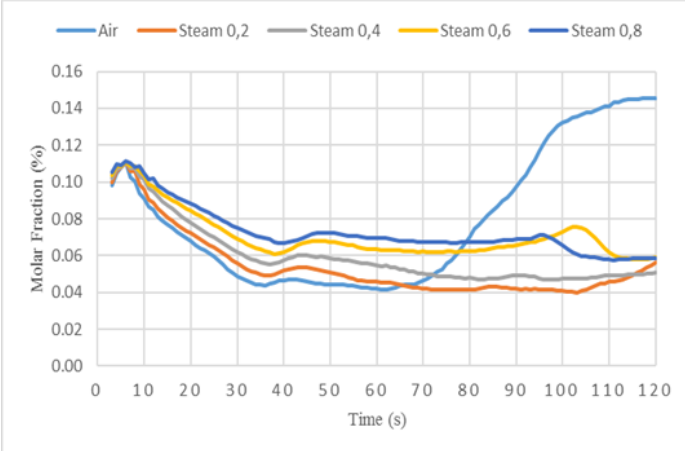

Figure 4. Changes of the molar fraction (\%) of CO versus time (s) in various cases (Table 6)

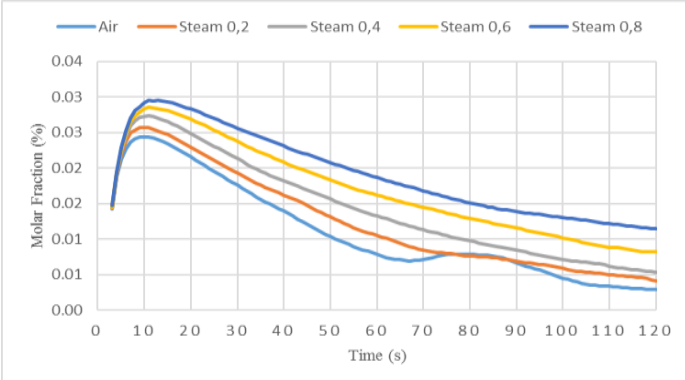

Figure 5. Changes of the molar fraction (\%) of $\mathrm{C}_{2} \mathrm{H}_{2}$ versus time (s) in various cases (Table 6)

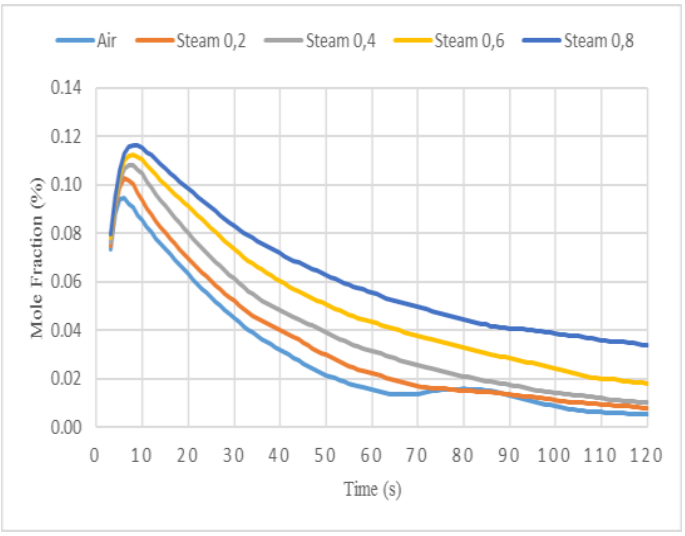

Figure 6. Changes of the molar fraction (\%) of $\mathrm{CH}_{4}$ versus time (s) in various cases (Table 6)

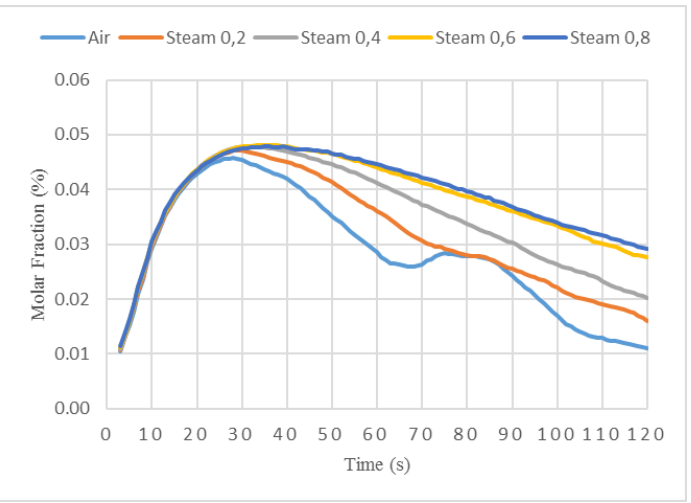

Figure 7. Changes of the molar fraction (\%) of $\mathrm{H}_{2}$ versus time (s) in various cases (Table 6)

Figure 4-7 described the changes of the molar fraction over time from 3 s to 120 s.

Overall, the composition of gas with using air-steam agent were higher than using air agent, except CO. Comparing the effect of different steam/air ratio, it could be seen that increase of the ratio result in higher molar fraction of gas $\left(\mathrm{C}_{2} \mathrm{H}_{2}, \mathrm{CH}_{4}, \mathrm{H}_{2}\right)$ caused by the transition of hydrogen from steam to syngas through gasification reactions and water-gas shift reaction.

In Figure 4, the amount of $\mathrm{CO}$ in process using air agent was increased dramatically at 70 s because the drying process was reached equilibrium. A decrease in moisture content drove a water gas shift reaction toward the side with more $\mathrm{CO}$.

This model using non-continuous approach resulted in decrease of combustible gas over time. 


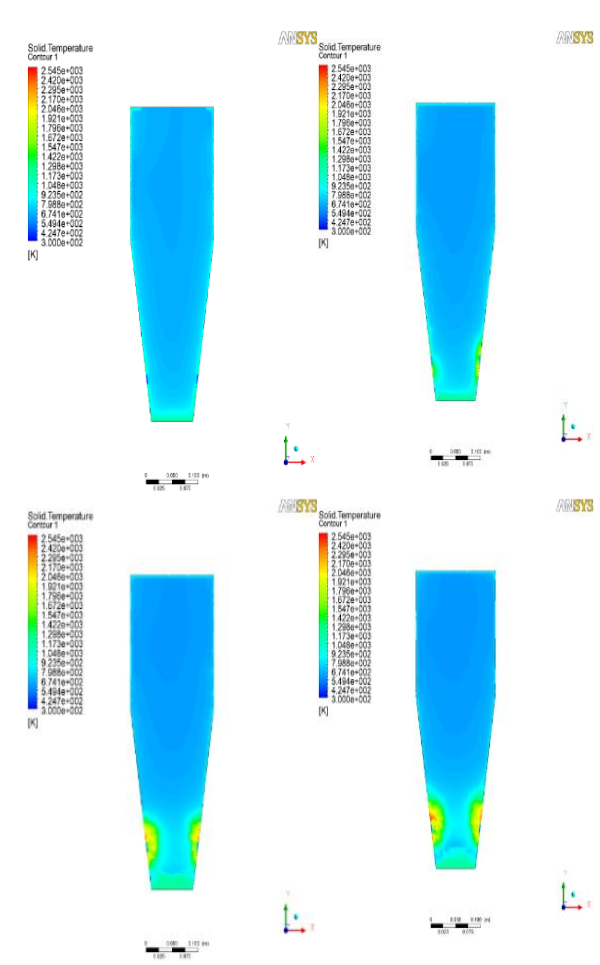

Figure 8. Contour of solid temperature at (a)30s, (b) 60s, (c)90s, (d)120s in case 1 (Table 6)

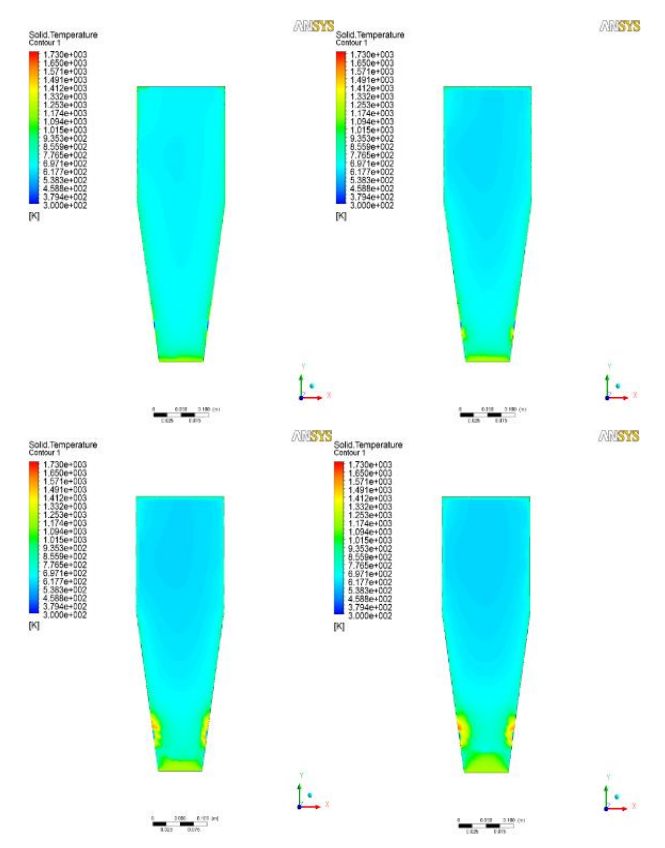

Figure 9. Contour of solid temperature at (a)30s, (b) 60s, (c)90s, (d)120s in case 2 (Table 6)

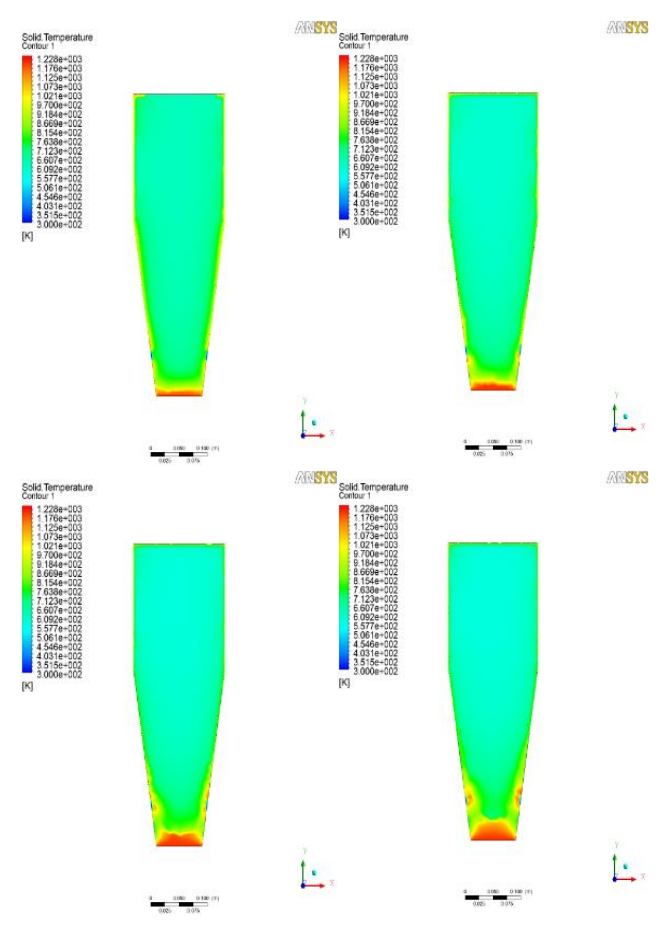

Figure 10. Contour of solid temperature at (a)30s, (b) 60s, (c)90s, (d)120s in case 3 (Table 6)

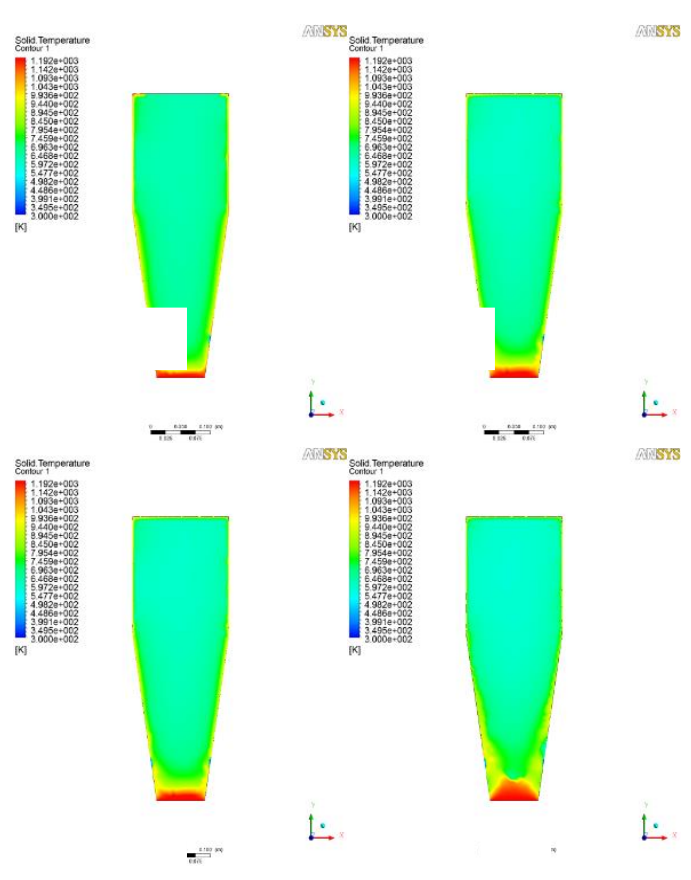

Figure 11. Contour of solid temperature at (a)30s, (b) $60 \mathrm{~s},(\mathrm{c}) 90 \mathrm{~s},(\mathrm{~d}) 120 \mathrm{~s}$ in case 4 (Table 6)

\section{Trang 104}




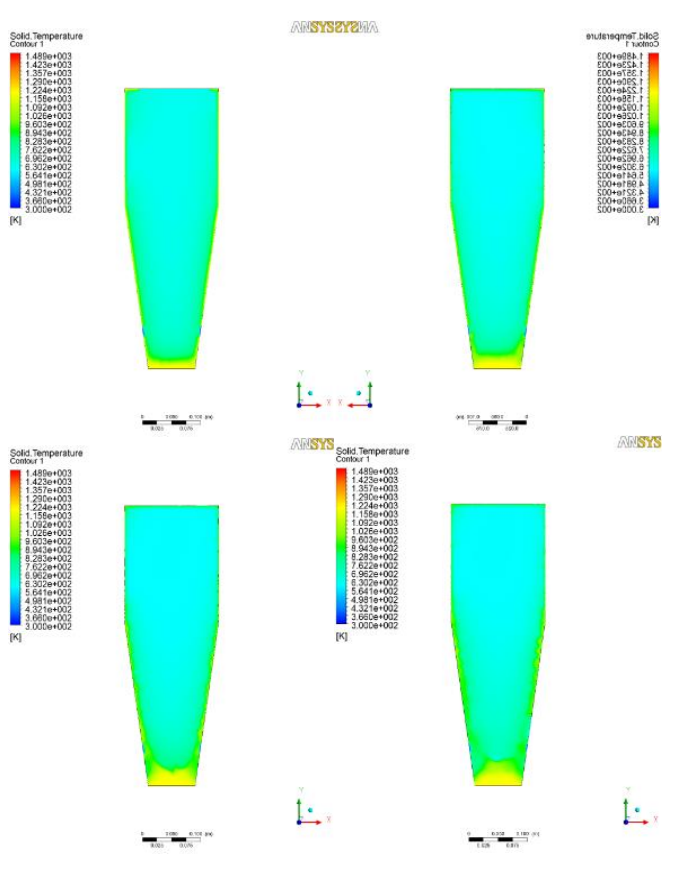

Figure 12. Contour of solid temperature at (a)30s, (b) $60 \mathrm{~s},(\mathrm{c}) 90 \mathrm{~s},(\mathrm{~d}) 120 \mathrm{~s}$ in case 5 (Table 6)

Figure 8 showed that the temperature surrounding air-supplying door was high dramatically It could be explained that combustion reactions occurred strongly and combustion zone gradually expanded over time because this was a batch-system. The amount of biomass reduced while gasification agents were fed constantly.

In Figure 8-12, while the steam content of the gasification agents was increasing, the temperature of the process decreased. Combustion process decreased and gasification one increased gradually which demonstrated gasification process was significantly affected by steam-air gasification agents.

Figure 12 showed that when steam-air gasification agent consisted of $80 \%$ steam, the temperature of areas in the process had the temperature ranging from $600 \mathrm{~K}$ to $700 \mathrm{~K}$ leading to gasification process operated more effectively.

Figure 13 shows validation of present model with experimental data [15] which was in well agreement. The average composition of $\mathrm{CO} 2, \mathrm{CO}, \mathrm{CH} 4, \mathrm{H} 2, \mathrm{~N} 2$ were compared with Raharjo 's calculation and experimental data from the rice husk gasification system using air agent. Table VII provides syngas composition results using air without steam as gasifying agent according to the experimental data, calculations and CFD model. The $\mathrm{H} 2 / \mathrm{CO}$ of CFD model obtained from Table VII was 0.362 , it was quite similar to the experimental data (0.348).

Figure 14 showed steam/air ratio was proportional with composition of $\mathrm{H} 2$ in both CFD model and experimental date [15]. It's also displayed experimental points was located quite close to the modelling points, so the simulation was quite suitable with experiment.

Table 7. Syngas composition results.

\begin{tabular}{|c|c|c|c|}
\hline \multirow[b]{2}{*}{ Comp } & \multicolumn{2}{|c|}{ Raharjo's literature } & \multirow[b]{2}{*}{$\begin{array}{c}\text { CFD } \\
\text { model } \\
\%\end{array}$} \\
\hline & $\begin{array}{c}\text { Experimental } \\
\text { data } \\
\%\end{array}$ & $\begin{array}{c}\text { Calculation } \\
\%\end{array}$ & \\
\hline $\mathrm{N}_{2}$ & 79.3842 & 55 & 63.6652 \\
\hline $\mathrm{H}_{2}$ & 1.2939 & 2.8243 & 4.3656 \\
\hline $\mathrm{CO}$ & 3.7162 & 8.1117 & 12.047 \\
\hline $\mathrm{CH}_{4}$ & 2.689 & 5.8695 & 4.4334 \\
\hline $\mathrm{CO}_{2}$ & 12.9168 & 28.1947 & 15.4889 \\
\hline Total & 100 & 100 & 100 \\
\hline
\end{tabular}




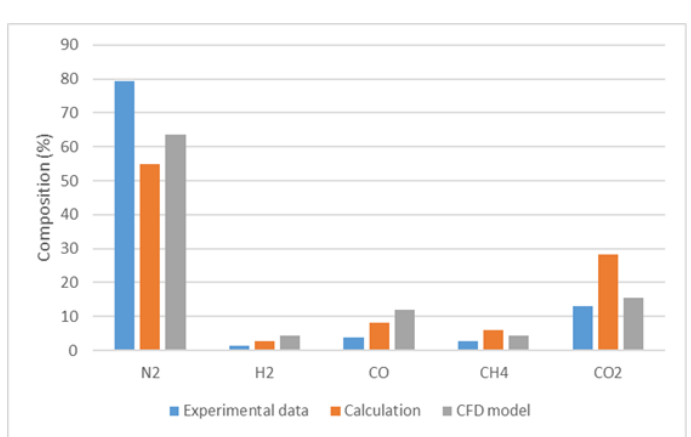

Figure 13. Model validation against Raharjo 's calculation and experimental data

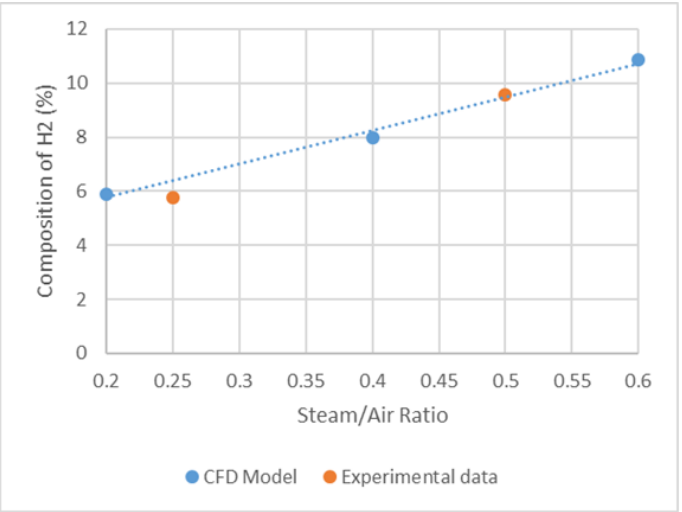

Figure 14. The effect of steam/air ratio on $\mathrm{H}_{2}$ compositions in both CFD model and experimental data.

\section{CONCLUSION}

The CFD model of gasification process with Euler-Euler approach combining with UDFs code was applied in this research. Entire process model was able to be simulated by $2 \mathrm{D}$ CFD model, it was important means in understanding mechanism of process and the composition of syngas, outlet temperature, velocities and reaction rates for the gas and solid phase in function of time and space. With non-continuous approach, the main disadvantage of this model was long computational time. The result from this research demonstrated the promising way to predict the effect of various gasification agents on composition of outlet-gas. This outcome can be used to maximize efficiency for operating updraft gasification system. Furthermore, the comprehensive CFD model and chemical kinetic model needed to be improved by more experimental work and further information about outlet syngas composition and temperature from pilot system.

Acknowledgements: This research was funded by Vietnam Government through the Project "Assessment and develop technological solutions for the efficient utilization of biomass resources (rice husk) to produce sustainable energy for the development of economy in Mekong Delta region"

\section{NOMENCLATURE}

A pre-exponent factor, particle surface area $1 / \mathrm{s}, \mathrm{m} 2$

Ap particle surface area (m2)

Cp specific heat capacity $\mathrm{J} / \mathrm{kgK}$

C2 inertial loss coefficient

Dg mass diffusion coefficient of gas $\mathrm{m} 2 / \mathrm{s}$

Dp mean particle diameter $\mathrm{m}$

E activation energy $\mathrm{kJ} / \mathrm{mol}$

hs convective mass transfer coefficient

hs' convection heat transfer coefficient $\mathrm{W} / \mathrm{m}^{2} \mathrm{~K}$

keff effective thermal conductivity $\mathrm{W} / \mathrm{mK}$

Pr Prandtl number

qr radiative flux density $\mathrm{W}$

Re Reynolds number

Sc Schmidt number

$\mathrm{S} \square$ source term

\section{Trang 106}


Tg gas temperature $\mathrm{K}$

Ts solid temperature $\mathrm{K}$

Tsatsaturated temperature $\mathrm{K}$

Yv mass fraction of volatile matter

$\mathrm{U}$ velocity component $\mathrm{m} / \mathrm{s}$

Greek letter

A absorption coefficient

permeability coefficient

$\phi \quad$ void fraction in bed

$\varepsilon$ dissipation rate of turbulent kinetic energy $\mathrm{m}^{-2} \mathrm{~s}^{-3}$
P density

$\lambda_{g}$ thermal dispersion coefficient

Subscripts

b Bulk

C char burnout

eff Effective

f Fluid

g Gas

p Particle

s Solid

sg solid to gas 


\section{Nghiên cứu CFD về khí hóa trấu trên hệ thống khí hóa ngược chiều quy mô pilot}

- Lê Thị Kim Phụng ${ }^{1}$

- Trần Tấn Việt ${ }^{1}$

- Nguyễn Lưu Minh Thiện ${ }^{1}$

- Phạm Vương Việt ${ }^{1}$

- Nguyễn Thanh Trúc ${ }^{1}$

- Lê Anh Kiên ${ }^{2}$

- Phạm Quốc Nghiệp ${ }^{2}$

- Lê Khắc Duyên ${ }^{2}$

${ }^{1}$ Trường Đại học Bách khoa, ĐHQG-HCM

${ }^{2}$ Viện Nhiệt đới môi trường

\section{TÓM TẮT}

Một trong nhũng vấn đề mà toàn cầu quan tâm là tìm kiếm năng luợng thay thế năng luợng hóa thạch, đặc biệt là ở các nuớc đang phát triển. Trấu, một sinh khối dồi dào tại Việt Nam, đã được sủ dụng để thay thế một phần nhiên liệu hóa thach bằng quá trình khí hóa. Nghiên cứ được tiến hành trên thiết bị khí hóa tầng cố với hai tác nhân khí hóa, không khí tinh khiết và hỗn hợp không khi-hơi nuớc. Mô hình toán học và mô phỏng bằng máy tínhđược sử dụng để mô tả và tối uu hóa các quá trình khí hóa. Mô hình toán họ dựa trên phuoong pháp Computational
Fluid Dynamics và mô phỏng được thưc hiện bằng cách sủ dụng phần mềm Ansys Fluent. Nhũng thay đổi trong thành phần đầu ra của các thành phần khí tổng hợp (CO, $\mathrm{CO}_{2}, \mathrm{CH}_{4}$, $\mathrm{H}_{2} \mathrm{O}, \mathrm{H}_{2}$ ) và nhiệt độ của quá trình, trong sư liên hệ với tỉ lệ của hơi nước trong tác nhân khí hóa cũng được trình bày trong tài liệu này. Kết quả thu được cho thấy nồng độ $\mathrm{CH}_{4}, \mathrm{H}_{2}$ trong khi đầu ra tăng lên đáng kể khi sử dụng tác nhân hoi-khí so với không khí. Sụ khác biệt giũa các tác nhân khí hóa được xác định để cải tiến quá trình thưc tế.

Tù khóa: CFD; khí hóa; trấu; Ansys Fluent; UDFs.

\section{REFERENCES}

[1]. Thanh Tu DANG, O. Saito , Yugo Yamamoto and A. Tokai, Scenarios for sustainable biomass use in the Mekong Delta, Vietnam, Journal of Sustainable
Energy \& Environment 1, Journal of Sustainable Energy \& Environment, 2010, pp. 137-148. 
[2]. Arvo Leinonen, Nguyen Duc Cuong, Development of biomass fuel chains in Viet Nam, 2013.

[3]. Prabir Basu, Biomass gasification and pyrolysis, Practical Design and Theory, 2010.

[4]. T. M. Ismail, M. Abd El-Salam, $A$ numerical model simulation for an updraft gasifier using high temperature steam, World Academy of Science, Engineering and Technology International Journal of Mechanical, Aerospace, Industrial, Mechatronic and Manufacturing Engineering Vol:8, No:5, 2014.

[5]. Roshan Budhathoki, "Three zone modeling of downdraft biomass gasification: Equilibrium and finite kinetic approach" Master's Thesis, Department of Chemistry, University of Jyvaskyla, 2013.

[6]. ANSYS FLUENT 12.0 User's Guide.

[7]. C. Mandl, I. Obernberger, F. Biedermann, Modelling of an updraft fixed-bed gasifier operated with softwood pellets, 2010.

[8]. Groenveld MJ, van Swaai WPM. Gasification of char particles with $\mathrm{CO}_{2}$ and $\mathrm{H}_{2} \mathrm{O}$. Chem Eng Sci; 35:307-13, 1980.
[9]. Babu BV, Sheth Pratik N. Modelling and simulation of reduction zone of downdraft biomass gasifer: effect of char reactivity factor, Energy Convers Manage, 2005.

[10].Bhagat PM. Wood charcoal combustion the effects of water application. Combust Flame;37:275-91, 1980.

[11].ANSYS FLUENT 12.0 Theory Guide.

[12].Biba V, Macak J, Klose E, Malecha J. Mathematical model for the gasification of coal under pressure, Ind Eng Process Des Dev; 17:92-8, 1978.

[13].ANSYS FLUENT 14.5 Database.

[14].Suhas D. Doke, Ganesh R. Kale, Sadanand Y. Guhe, Thermodynamic modeling and experimental study of rice husk pyrolysis, International Journal of Research in Engineering and Technology, 2015.

[15].Bambang Suwondo Rahardjo, Effect of gasifying agent (air + steam) injection towards syngas quality from rice husk gasification, International Journal of Engineering and Applied Sciences, 2013. 